\title{
An Improved Method for Elimination of Holotrich Protozoa from Mixed Rumen Protozoal Suspension by Mannose-Treatment
}

\author{
Ryoji ONODERA and Miyuki YAKIYAMA \\ Department of Animal Science, Faculty of Agriculture, \\ Miyazaki University, Miyazaki shi 889-21
}

(Received December 26, 1988)

\begin{abstract}
An improvement was made of a method to eliminate holotrich protozoa from mixed rumen protozoa in this study. Mixed rumen protozoal suspension obtained from a goat was incubated at $39^{\circ} \mathrm{C}$ in various levels of D-mannose solutions (up to $6 \%(\mathrm{w} / \mathrm{v})$ in buffer solutions). As a result, treatment with a $4 \%(\mathrm{w} / \mathrm{v})$ D-mannose solution (isotonic to about $0.250 \mathrm{M}$ sucrose) for $1 \mathrm{hr}$ and further successive treatment for $2 \mathrm{hr}$ in the same solution, which was just supplemented at this point with $\mathrm{D}$-mannose equivalent to $2 \%(\mathrm{w} / \mathrm{v})$ of the solution, was shown to be enough to completely eliminate holotrich protozoa from the mixed rumen protozoa, where the density of holotrich protozoa was up to about $40 \times 10^{3} / \mathrm{m} l$ (Isotricha: up to $25 \times 10^{3} / \mathrm{ml}$; Dasytricha: $15 \times 10^{3} / \mathrm{m} l$ ) in the present experiment. The present improved method saved three hours to eliminate holotrichs compared to the previous method. It was also shown that Isotricha tended to consume D-mannose more rapidly than Dasytricha.
\end{abstract}

Jpn. J. Zootech. Sci., $60(6): 602-608,1989$

Key words : rumen protozoa, holotrichs, entodiniomorphs, mannose

Among rumen ciliate protozoa, the food habit and metabolism have been shown to be partly different between holotrich protozoa and entodiniomorphid ones. For example, holotrich protozoa can ferment both soluble sugars and particulate polysaccharides like starch, while entodiniomorphid protozoa can ferment starch but not soluble sugars so rapidly and are referred to as particle feeders ${ }^{1)}$. Similar observation was also reported as to protein degradation ${ }^{2,3)}$. Recent studies showed that plant fibre-degrading enzyme activities of entodiniomorphid protozoa were generally higher than those of holotrich protozoa ${ }^{4,5)}$. In this connection, if we can establish a convenient method to eliminate holotrichs from mixed rumen protozoa, it is extremely useful for investigations directly for entodiniomorphs and indirectly for holotrichs. We have previously succeeded in eliminating all holotrich protozoa by incubating mixed rumen protozoa in $1.2 \% \mathrm{D}$-mannose-containing buffer solution at $39^{\circ} \mathrm{C}$ for $6 \mathrm{hr}^{3)}$ and this method has been applied to the examination of in vitro digestibility trials for only entodiniomorphid protozoa ${ }^{3,6)}$. But there is one problem in this method. That is the length of incubation time $(6 \mathrm{hr})$ until eliminating all holotrichs. 
In the present paper, examinations were carried out for the rapid elimination of holotrichs.

\section{Materials and Methods}

1. Isolation of rumen ciliate protozoa

Rumen ciliate protozoa were collected from the rumen contents of a ruminally fistulated goat (Japanese local breed, $45 \mathrm{~kg}$ ) fed on a ration consisting of haycube $(600 \mathrm{~g} /$ day $)$ and a concentrate $(200 \mathrm{~g} /$ day, formula feed : alpha-topbeef, Chubu-shiryo, Japan) twice daily at $09: 00$ and $17: 00$. The protozoal suspension was prepared using MB 9 buffer solution" in the same manner as described previously ${ }^{8}$.

2. Incubation procedure for treatment with $\mathrm{D}$-mannose and sample treatment

The ciliate suspension $(4 \% \mathrm{v} / \mathrm{v})$ was incubated in MB 9 buffer solution or in various levels of D-mannose-containing buffer solution (Table 1 ) at $39^{\circ} \mathrm{C}$ up to $6 \mathrm{hr}$. These solutions contained $0.1 \mathrm{mg}$ each $/ \mathrm{ml}$ of dihydrostreptomycin sulfate, penicillin $\mathrm{G}$ potassium and chloramphenicol sodium succinate to inhibit the growth of contaminating bacteria.

After incubation, a $0.5-\mathrm{m} l$ portion of the suspension was collected with stirring, mixed with $9.5 \mathrm{~m} l$ of MFS solution ${ }^{9)}$, a kind of fixative solution, and kept at room temperature. A $0.005-\mathrm{m} l$ portion of the fixed ciliate suspension was used for counting of protozoa on a Fuchs-Rosenthal hemacytometer under microscope.

\section{Results and Discussion}

Based on the original report by ABou AKKADA and HowARD ${ }^{10)}$ that overnight incubation in $0.6 \%$ D-mannose solution killed Dasytricha ruminantium, we have previously tried and succeeded in total elimination of holotrich protozoa (Dasytricha and Isotricha) from mixed rumen ciliate protozoa by incubating them at $39^{\circ} \mathrm{C}$ for $6 \mathrm{hr}$ in a $1.2 \%$ D-mannose-containing B-9 buffer solution, whose osmorality had been adjusted so as to be isotonic to $0.25 \mathrm{M}$ sucrose by decreasing $\mathrm{NaCl}^{3)}$. Thus the effect of the enhanced level of D-mannose in MB 9 buffer solution (where isotonicity was not adjusted) on the mortality of holotrich protozoa was examined to prospect the possibility to shorten the incubation time to kill them. Results showed that

Table 1. Composition of buffer solutions

\begin{tabular}{|c|c|c|c|c|}
\hline Composition & MB9 & $2 \%$ & $\begin{array}{c}\text { D-mannose solution } \\
4 \%\end{array}$ & $6 \%$ \\
\hline $\mathrm{NaCl}$ & 2.8 & 2.9 & 0 & 0 \\
\hline $\mathrm{CaCl}_{2} 2 \mathrm{H}_{2} \mathrm{O}$ & 0.1 & 0.1 & 0.1 & 0.1 \\
\hline $\mathrm{MgSO}_{4} 7 \mathrm{H}_{2} \mathrm{O}$ & 0.1 & 0.1 & 0.1 & 0.1 \\
\hline $\mathrm{KH}_{2} \mathrm{PO}_{4}$ & 2.0 & 0.5 & 0.5 & 0.5 \\
\hline $\mathrm{Na}_{2} \mathrm{HPO}_{4}$ & 6.0 & 1.5 & 1.5 & 1.5 \\
\hline D-mannose & 0 & 20.0 & 40.0 & 60.0 \\
\hline $\begin{array}{l}\text { Isotonicity to } \\
\text { sucrose (M) }\end{array}$ & 0.250 & 0.248 & 0.261 & 0.369 \\
\hline
\end{tabular}




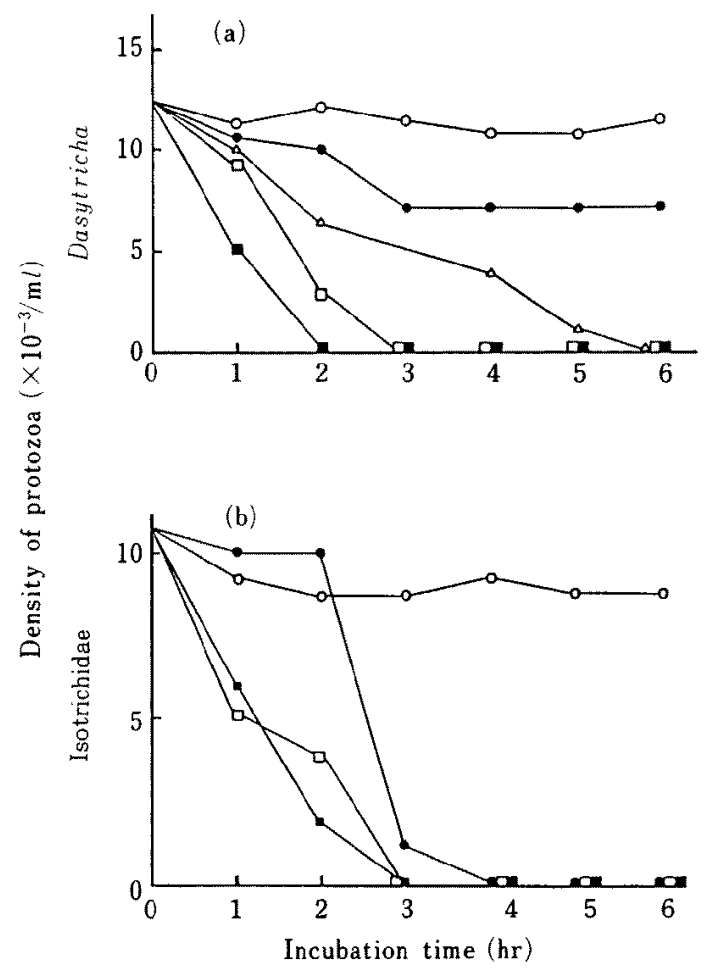

Fig. 1. Effect of D-mannose levels on the mortality of holotrich protozoa. (a) Effect on Dasytricha: Control (O), $0.6 \%(\bullet), 1.2 \%$ $(\triangle), 2.4 \%(\square), 3.6 \%(\square)$; (b) Effect on Isotrichidae : Control $(O), 2$ $\%(\mathbf{O}), 4 \%(\square), 6 \%(\mathbf{\square})$.

enhancement of D-mannose level surely shortened the time to eliminate holotrichs and $3.6 \%$ D-mannose killed them within $2 \mathrm{hr}$ as shown in Fig. 1-a. But in this case, the higher the mannose level, the higher the mortality of all protozoa including entodiniomorphid ones. Namely 5\% D-mannose in MB 9 killed all protozoa within 90 min and more than $10 \% \mathrm{D}$-mannose within $10 \mathrm{~min}$, though these were not shown in Fig. 1. These results suggested that the osmorality of the D-mannose solution should be adjusted to be isotonic to about $0.250 \mathrm{M}$ sucrose as previously reported ${ }^{11}$.

Then 2, 4 and 6\% D-mannose-containing buffer solutions (Table 1) were prepared so as to be isotonic to near $0.250 \mathrm{M}$ sucrose except for $6 \%$ in the same manner as preparing $\mathrm{MB} 9$ ( $\mathrm{pH} 6.8$ and anaerobic) ${ }^{8}$. Results of the first trial for incubation of the mixed rumen ciliates in these buffer solutions with or without D-mannose showed that 4 and $6 \%$ D-mannose solution killed all of Isotrichidae within $3 \mathrm{hr}$ (Fig. 1-b). In this experiment, the densities of Isotricha and Dasytricha were both $5.3 \times 10^{3} / \mathrm{m} l$, respectively.

In the second trial, however, Dasytricha (original density : $14.8 \times 10^{3} / \mathrm{m} l$ ) did not disappear even after incubation for $6 \mathrm{hr}$ in $6 \%$ D-mannose solution (Fig. 2-b), though Isotricha (original density : $18.4 \times 10^{3} / \mathrm{m} l$ ) completely disappeared within $2 \mathrm{hr}$ in each 
D-mannose level (Fig, 2-a), Other entodiniomorphid protozoa remained almost unchanged (Fig. 2-c). From these results, we surmised that high density of Isotricha might so quickly consume D-mannose that the protozoa died shortly and the concentration of D-mannose in the medium quickly decreased to the level not enough to kill Dasytricha, where Dasytricha might tend to incorporate D-mannose at a comparatively slow rate and their incorporation rate might be influenced by the concentration of D-mannose.

Then in the third trial, D-mannose equivalent to $2 \%(\mathrm{w} / \mathrm{v})$ was supplemented to the incubation medium after $1-\mathrm{hr}$ incubation of mixed rumen protozoal suspension which contained especially high density of Isotricha $\left(24.8 \times 10^{3} / \mathrm{ml}\right)$. In this case, Isotricha disappeared quickly again as shown in Fig. 3-a and Dasytricha also
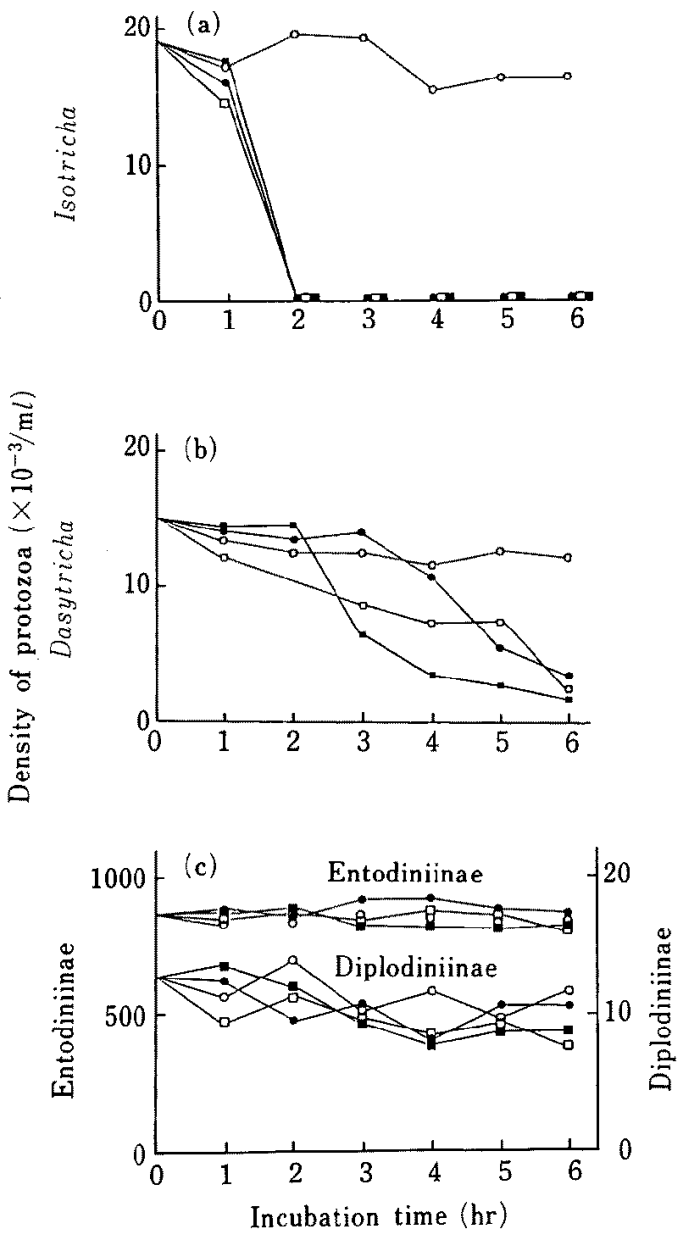

Fig. 2. Effect of D-mannose levels on the mortality of Isotricha (a), Dasytricha (b) and entodiniomorphid protozoa (c). D-

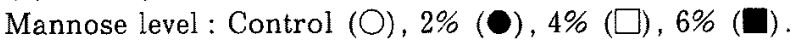


disappeared within $4 \mathrm{hr}$ for $2 \%$ and $3 \mathrm{hr}$ for 4 and $6 \% \mathrm{D}$-mannose solution (initial levels) as was expected (Fig. 3-b). Entodiniinae and Diplodiniinae remained almost unchanged in 2 and $4 \%$ D-mannose, but in $6 \%$ they tended to decrease (Fig. 3-c and d).

In the final experiment, ciliate suspensions containing two grades of densities of Isotricha were incubated in only $4 \% \mathrm{D}$-mannose solution to confirm whether the supplementation of $\mathrm{D}$-mannose after $1 \mathrm{hr}$ incubation could efficiently shorten the life of Dasytricha especially when the density of Isotricha was high. Results were shown in Fig. 4-a and b. Isotricha disappeared indubitably within $2 \mathrm{hr}$ when D-mannose equivalent to $2 \%(\mathrm{w} / \mathrm{v})$ of the incubation medium was supplemented after $1 \mathrm{hr}$ incubation (Fig. 4-a). It was also confirmed that the life of Dasytricha was efficiently shortened by the supplementation of D-mannose, dying within $3 \mathrm{hr}$ even when the density of Isotricha was very high $\left(23.6 \times 10^{3} / \mathrm{m} l\right)$ (Fig. 4-b). Entodiniomorphid protozoa remained almost unchanged. From these results, Isotricha seemed to have a tendency to consume D-mannose more rapidly than Dasytricha and to disappear quickly.

These results led us to the conclusion that all holotrich protozoa (density of Isotricha: up to $25 \times 10^{3} / \mathrm{ml}$, and that of Dasytricha: up to $15 \times 10^{3} / \mathrm{m} l$ in the present experiments) could be eliminated by incubating in $4 \%(\mathrm{w} / \mathrm{v})$ D-mannose solution (Table 1) for $1 \mathrm{hr}$ and then continuing incubation for $2 \mathrm{hr}$ just after D-mannose

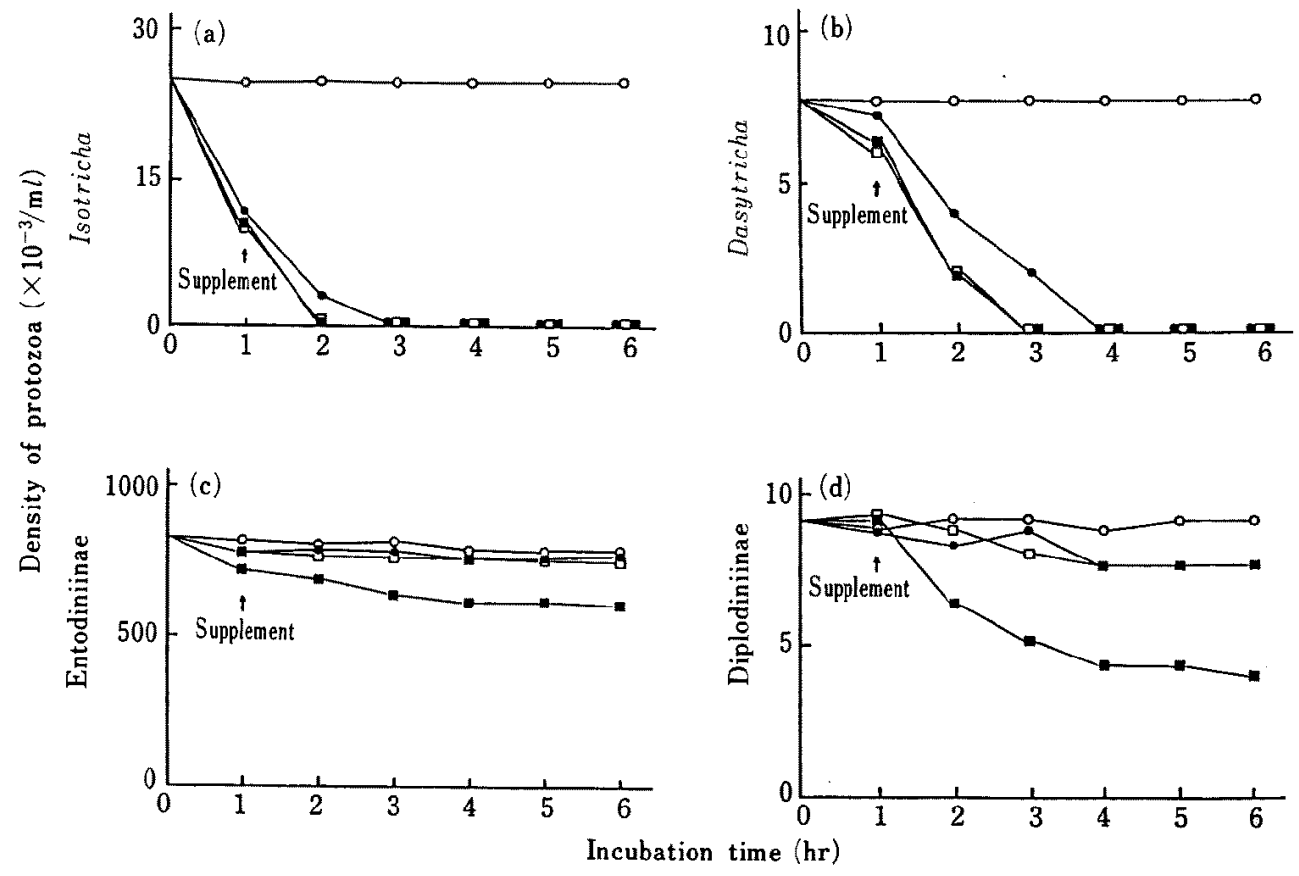

Fig. 3. Effect of the supplementation of D-mannose $(2 \%(\mathrm{w} / \mathrm{v})$ of the incubation medium) after 1-hr incubation of mixed rumen protozoa in the medium containing $0 \%$

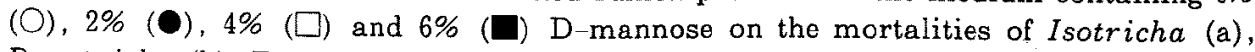
Dasytricha (b), Entodiniinae (c) and Diplodiniinae (d). 


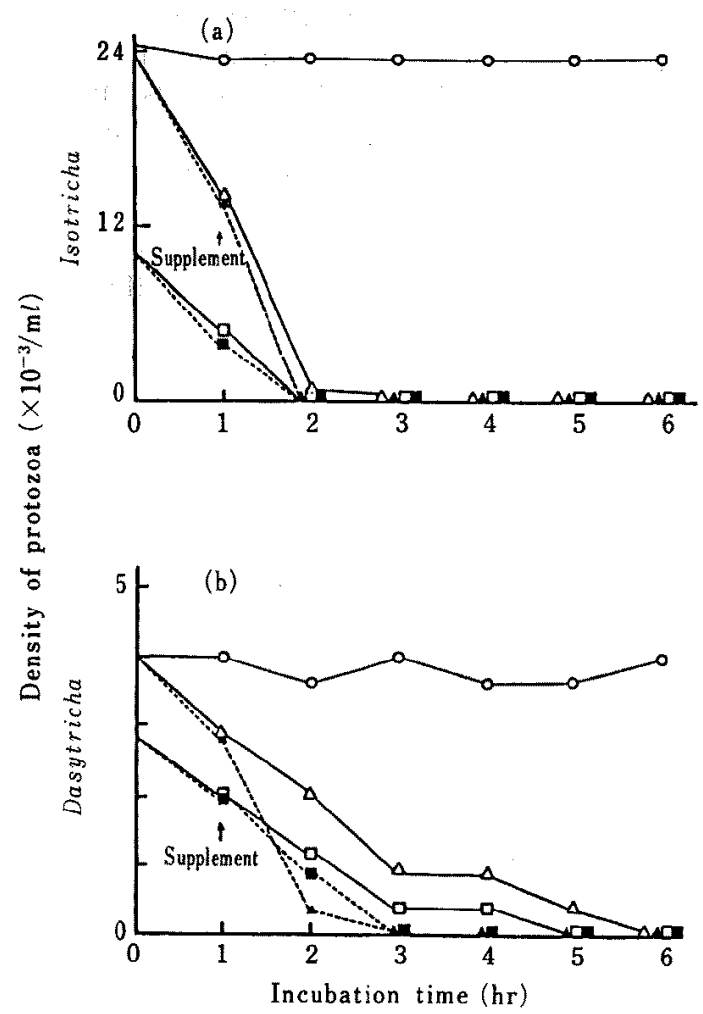

Fig. 4. Effect of the supplementation (broken lines with symbols $(\Delta)$ and (耳)) and non-supplementation (solid lines with symbols $(\triangle)$ and $(\square)$ ) of $D$-mannose (2\% (w/v) of the incubation medium) after 1-hr incubation of mixed rumen protozoal suspensions containing two grades of density of Isotricha (high grade: $(\triangle)$ and $(\Delta)$; low grade: $(\square)$ and $(\square)$ ) in $4 \% D$-mannose solution on the mortalities of Isotricha (a) and Dasytricha (b). Control (with high density of Isotricha and without D-mannose) was shown by a symbol $(O)$.

equivalent to $2 \%(\mathrm{w} / \mathrm{v})$ was added to the incubation medium. Thus we could get a holotrichs-free rumen ciliate protozoal suspension after collecting the treated protozoa by centrifugation $(1000 \times \mathrm{g}$, for $3 \mathrm{~min})$ and washed with warmed MB 9 buffer solution three times. By this study, we could save three hours for the elimination of holotrich protozoa from mixed rumen protozoa.

\section{References}

1) Coleman G.S., FEMS Microbiology Rev., 39 : 321-344. 1986.

2) Onodera, R. and M. Kandatsu, Jpn. J. Zootech. Sci., $41: 307-313.1970$.

3) Onodera, R.,Y. Toyofuku, S. Fujita, S. Nakahara and M. Kandatsu, Jpn. J. Zootech. Sci., 45:652-656. 1974.

4) Williams, A.G., S.E. Withers and G.S. Coleman, Curr. Microbiol., $10: 287-294$. 1984. 


\title{
ONODERA and YAKIYAMA
}

5) Coleman, G.S., J. agric. Sci., Camb. 104: 349-360. 1985.

6) Ushida, K., T. Kaneko and Y. KoJima, Jpn. J. Zootech. Sci., 58 : 893-902. 1987.

7) Onodera, R. and C. Henderson, J. Appl. Bacteriol., 48 : 125-134. 1980.

8) OnOdera, R., Appl. Environ. Microbiol., 51 : 1350-1351. 1986.

9) Onodera, R., H. Yamaguchi, C. Eguchi and M. Kandatsu, Agric. Biol. Chem., 41 : 2465-2466. 1977 .

10) Abou AkKadA, A.R. and B.H. Howard, Biochem. J., 76 : 445-451. 1960.

11) Onodera, R. and M. Kandatsu, Jpn. J. Zootech. Sci., 41 : 343-348. 1970.

\section{マンノース処理による混合ルーメン繊毛虫類からの 全毛類除去法の改良}

\author{
小野寺良次・焼山美由紀 \\ 宮崎大学農学部，宮崎市 889-21
}

本研究では，混合ルーメン䋐毛虫類から全毛類を完全 除去する力法の改良を行なった。目羊加ら得た湿合ルー

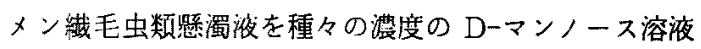

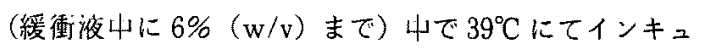
ベートした，その結果， $4 \%(w / v)$ D-マンノース溶液 (約 $0.250 \mathrm{M}$ ショ糖液に等張) で 1 時間処理をし, 続い て,この溶液に, さらに, $2 \%(\mathrm{w} / \mathrm{v})$ 分の D-マン, 一スを迎加した溶陵山で 2 時閆処理を続けると，混合ル
ーメン緎毛虫類から全毛類が完全に除去されることが示 された，本研究では，全毛類の密度は，最高時で，約 $40 \times 10^{3} / \mathrm{ml}$ (Isotricha: $25 \times 10^{3} / \mathrm{ml}$ : Dasytricha : $\left.15 \times 10^{3} / \mathrm{m} l\right)$ であった．本研究により，全毛類の除去 に要する時間を以前よりも 3 時間節約することができた。 また, Isotrichaは, Dasytrichaよりあ速く D-マン ノースを摄取する傾向が認められた。

日畜会報，60(6)：602-608，1989 